Sains Peternakan Vol. 6 (1), Maret 2008: 18-25

ISSN $1693-8828$

\title{
Transfer Omega-3 Melalui Kapsulisasi dan L-Karnitin Pengaruhnya Terhadap Kandungan Asam Lemak Daging dan Sate Kambing
}

\author{
Sudibya \\ Jurusan Peternakan, Fakultas Pertanian, Universitas Sebelas Maret \\ Jl. Ir. Sutami 36 A, Kentingan, Surakarta \\ Email: sudibya@uns.ac.id
}

\section{INTISARI}

Tujuan penelitian ingin mengetahui dan membandingkan pengaruh suplementasi Lkarnitin dan minyak ikan tuna serta minyak ikan lemuru terhadap konsentrasi asam lemak dan angka peroksida pada daging dan sate kambing.

Materi penelitian yang digunakan adalah 20 ekor kambing jantan Peranakan Etawah (PE) dengan umur 2 sampai 3 bulan dan bobot badan (BB) berkisar 15,5 sampai 23,5 kg. Bahan pakan yang digunakan terdiri atas rumput lapang, jagung kuning, bekatul, bungkil kedelai, bungkil kelapa, mineral, premik, L-karnitin, minyak ikan tuna dan minyak ikan lemuru. Metode penelitian adalah eksperimental secara in vivo menggunakan Rancangan Acak Kelompok (RAK) dengan 4 perlakuan dengan 5 blok sebagai ulangan. Setiap unit blok berisi 1 ekor kambing jantan. Perlakuannya yaitu : $\mathrm{P}_{0}=$ Ransum kontrol, $\mathrm{P}_{1}=\mathrm{P}_{0}+\mathrm{L}-$ karnitin 50 ppm, $\mathrm{P}_{2}=\mathrm{P}_{1}+$ minyak ikan tuna $5 \mathrm{ml}$ setara $4 \%$ dalam ransum, dan $\mathrm{P}_{3}=\mathrm{P}_{1}+$ minyak ikan lemuru $5 \mathrm{ml}$ setara $4 \%$ dalam ransum.. Peubah yang diukur adalah konsentrasi asam lemak dan angka peroksida pada daging dan sate kambing.

Hasil analisis variansi menunjukkan bahwa suplementasi minyak ikan tuna serta minyak ikan lemuru hingga level $5 \mathrm{ml}$ per ekor dalam ransum kambing yang mengandung 50 ppm L-karnitin berpengaruh sangat nyata $(\mathrm{P}<0,01)$ terhadap asam lemak jenuh dan asam lemak tak jenuh serta angka peroksida pada daging sate kambing.

Kesimpulan dari penelitian adalah suplementasi minyak ikan tuna serta minyak ikan lemuru hingga level $5 \mathrm{ml}$ per ekor dalam ransum kambing yang mengandung $50 \mathrm{ppm}$ L-karnitin mampu meningkatkan kadar asam lemak tak jenuh dari 59,74 menjadi $67,36 \%$. Selanjutnya peningkatan tersebut diikuti dengan turunnya kadar asam lemak jenuh daging kambing mulai 40,26 hingga 32,64\%. Proses pembakaran (sate kambing) mampu menaikan angka peroksida dari 0,1437 hingga 0,1635 miliequivqlen per $\mathrm{kg}$ lemak dan bilangan TBA dari 1,807 menjadi 2,440 mg/kg lemak akan tetapi menurunkan kadar asam lemak omega-3 dari 5,957 \% menjadi 5,945\%.

Kata Kunci: asam lemak jenuh, tak jenuh, angka peroksida, TBA, L-karnitin, minyak ikan tuna, minyak ikan lemuru, sate kambing

\section{Transfer Omega-3 Capsulitation and L-Carnitine for Concentration Fatty Acids Meats and Burner Metas Goat}

ABSTRACT 
The objective of this study were to find out and to compare the effect of supplementation of L-carnitine and tuna fish oil and lemuru fish oil on fatty acid saturated, fatty acid non saturated concentration and peroksida, TBA number.

The materials used were 20 male PE (Peranakan Etawah) goats of 2 until 3 month old and 15.5-23.5 kilogram body weight. The feedstuff used were wild grass, yellow corn, rice bran, soy bean meal, coconut meal, mineral premix. L-carnitine, tuna fish oil and lemuru fish oil. The method of the research was experimental in vivo using Completely Randomized Blok Design. There were 4 treatments in each treatment and 5 replication. Treatment consisted of $P_{0}=$ control ration, $P_{1}=P_{0}+L$-carnitine 50 ppm, $P_{2}=P_{1}+$ tuna fish oil $5 \mathrm{ml}$ or equal with $4 \%$ in the ration, and $P_{3}=P_{1}+$ lemuru fish oil 5 $\mathrm{ml}$ or equal with $4 \%$ in the ration. The variables measuared fatty acid saturated, fatty acid non saturated concentration and peroksida number..

The results of variance analysis showed that the effect of supplementation of tuna fish oil and lemuru fish oil $\left(P_{2}\right.$ and $\left.P_{3}\right)$ in the rations contain 50 ppm L-carnitine were significantly $(P<0.01)$ on faty acid saturated, faty acid non saturated concentration and peroksida number.

The conclusion of this research shows that the supplementation of $50 \mathrm{ppm} \mathrm{L-}$ carnitine, tuna and lemuru fish oil $5 \mathrm{ml}$ that was equal to $4 \%$ in goat rations can incrase non saturated fatty acid from 59,74 to 67,36\%, than to decreased saturated fatty acid from 40,26 to 32,64\%. Proces burned of meat goat to increase peroxida from 0.1437 until 0.1615 miliequivalen $/ \mathrm{kg}$ and malonaldehyde from 1,807 until 2,440 $\mathrm{mg} / \mathrm{kg}$ then to decrease concentration omega-3 fatty acid from 5,957 until 5,945\%.

Key words : saturated fatty acid, non saturated fatty acid, L-carnitine, tuna, lemuru fish oils

\section{PENDAHULUAN}

Minyak ikan merupakan sumber lemak. Manipulasi metabolisme lemak dalam rumen ditujukan untuk menghasilkan dua partikel yang pertama absorpsi asam lemak yang dikehendaki untuk meningkatkan kualitas nutrisi produk ternak (Chillard, 1993 ). Suplementasi minyak ikan dalam pakan harus dengan dosis tertentu agar tidak mengganggu aktivitas mikroorganisme rumen. Jenkins (1993) menyatakan bahwa penambahan minyak ikan dalam pakan ruminansia tidak boleh lebih dari 6 sampai $7 \%$ dari bahan kering ransum karena akan mempengaruhi fermentasi mikroorganisme rumen. Menurut Sudibya (1998) fungsi asam lemak omega-3 dalam mengontrol pengaruh antimikroba dari asam lemak untuk meminimkan gangguan fermentasi rumen, sehingga level lemak tertinggi dapat dimasukkan dalam pakan, kedua mengontrol biohidrogenasi untuk meningkatkan

menurunkan kadar kolesterol melalui dua cara yakni 1). merangsang ekskresi kolesterol melalui empedu dari hati ke dalam usus dan 2). merangsang katabolisme kolesterol oleh HDL ke hati kembali menjadi asam empedu dan tidak diregenerasi lagi namun dikeluarkan bersama ekskreta.

\section{MATERI DAN METODE}

Materi yang digunakan adalah 20 ekor kambing jantan PE dengan umur 2 sampai 
3 bulan dan BB berkisar 15,5 sampai 23,5 $\mathrm{kg}$; pakan yang terdiri atas rumput lapang, jagung kuning, bekatul, bungkil kedelai, bungkil kelapa, mineral, premik, Lkarnitin, ekstrak asam lemak omega-3 yang diperoleh dari minyak ikan tuna dan minyak ikan lemuru serta cangkang Kapsul buatan PT Capsulindo dengan kapasitas 5ml/ kapsul. Metode penelitian adalah eksperimental secara in vivo menggunakan Rancangan Acak Kelompok dengan 4 perlakuan dengan 5 blok sebagai ulangan, setiap unit blok berisi 1 ekor kambing jantan. Adapun perlakuannya yaitu : $\mathrm{P}_{0}=$ Ransum kontrol, $\mathrm{P}_{1}=\mathrm{P}_{0}+\mathrm{L}$ karnitin $50 \mathrm{ppm}, \mathrm{P}_{2}=\mathrm{P}_{1}+$ minyak ikan tuna $5 \mathrm{ml}$ setara $4 \%$ dalam ransum, dan $\mathrm{P}_{3}=\mathrm{P}_{1}+$ minyak ikan lemuru $5 \mathrm{ml}$ setara $4 \%$ dalam ransum. Peubah yang diukur adalah konsentrasi asam lemak jenuh dan tak jenuh pada daging segar, asam lemak omega-3 pada daging dan sate kambing serta angka peroksida dan bilangan TBA pada daging dan sate kambing.

\section{Analisis Data}

Data dianalisis dengan sidik ragam dan dilanjutkan uji kontras orthogonal (Steel dan Torrie, 1980). Model matematik yang digunakan yaitu :

$$
Y_{i j}=\mu+\rho+\alpha i+\varepsilon_{i j}
$$

$(i=1,2,3$ dan $4 ; j=1,2,3,4$ dan 5)

Keterangan :

$\mathrm{Y}_{\mathrm{ij}}=$ Pengamatan pada unit eksperimen ke-j dalam suplementasi L-karnitin dan minyak ikan tuna serta minyak ikan lemuru ke-i

$\mu=$ Rataan umum

$\rho=$ Pengaruh blok terhadap perlakuan

$\alpha_{i}=$ Pengaruh suplementasi L-karnitin dan minyak ikan tuna serta minyak ikan lemuru ke-i

$\varepsilon_{\mathrm{ij}}=$ Pengaruh kesalahan percobaan kedalam suplementasi L- karnitin dan minyak ikan tuna serta minyak ikan lemuru ke-i

\section{HASIL DAN PEMBAHASAN}

\section{Kadar Asam Lemak Tak Jenuh Daging Kambing Segar}

Kadar asam lemak tak jenuh yang tertinggi pada perlakuan $\mathrm{P}_{3}$ yakni $67,36 \%$ sedangkan yang terendah pada perlakuan $\mathrm{P}_{0}$ yakni $59,74 \%$. Data selengkapnya dapat dilihat pada Tabel 1. Dari uji lanjut orthogonal kontras terlihat bahwa kadar asam lemak tak jenuh pada $\mathrm{P}_{0}$ berbeda sangat nyata dengan $\mathrm{P}_{1}, \mathrm{P}_{2}$ dan $\mathrm{P}_{3}$, selanjutnya $P_{1}$ berbeda sangat nyata dengan $\mathrm{P}_{2}$ dan $\mathrm{P}_{3}$ sedangkan $\mathrm{P}_{2}$ tidak berbeda nyata dengan $\mathrm{P}_{3}$. Kadar asam lemak tak jenuh yang ditambah L-karnitin $\left(\mathrm{P}_{1}\right)$ tidak mengalami kenaikan bila dibanding pada $\mathrm{P}_{0}$ hal ini sejalan dengan pendapat ( Owen et al., 1996 ) yang menyatakan bahwa suplementasi Lkarnitin tidak dapat digunakan untuk meningkatkan kadar asam lemak tak jenuh karena L-karnitin sendiri tidak mengandung asam lemak tak jenuh.

Tabel 1. Rataan Kadar Asam Lemak Tak Jenuh Pada Daging Kambing Segar

\begin{tabular}{lcccc}
\hline \multicolumn{1}{c}{ Peubah yang diukur } & $\mathrm{P}_{0}$ & $\mathrm{P}_{1}$ & $\mathrm{P}_{2}$ & $\mathrm{P}_{3}$ \\
\hline Kadar asam lemak tak jenuh (\%) & $59,74^{\mathrm{a}}$ & $59,70^{\mathrm{a}}$ & $67,38^{\mathrm{b}}$ & $67,36^{\mathrm{b}}$ \\
Kadar asam lemak jenuh (\%) & $40,26^{\mathrm{a}}$ & $40,30^{\mathrm{a}}$ & $32,62^{\mathrm{b}}$ & $32,64^{\mathrm{b}}$ \\
\hline
\end{tabular}

* Huruf superskrip yang berbeda pada baris yang sama menunjukkan adanya perbedaan yang sangat nyata $(\mathrm{P}<0,01)$ 
Selain itu penambahan minyak ikan dapat menaikkan kandungan asam lemak tak jenuh, hal ini dapat dijelaskan selain minyak sebagai sumber energi juga dapat sebagai sumber asam lemak tak jenuh sehingga mampu menaikkan kadar asam lemak tak jenuh dalam daging kambing. Hal ini sejalan dengan pendapat Suarez et al. (1996) yang menyatakan bahwa suplementasi asam lemak tak jenuh pada ransum berpengaruh terhadap konsentrasi asam lemak tak jenuh pada jaringan tubuh. Selanjutnya bila dibandingkan penelitian Sudibya et al. $(2003$; 2006) yang menyatakan bahwa kandungan asan lemak tak jenuh pada daging sapi potong yang disuplementasi dengan minyak ikan lemuru sebesar $69,60 \%$ pada penelitian ini masih dalam batas normal.

Pada penelitian ini kandungan asam lemak tak jenuh mencapai $67,36 \%$, hal ini sangat menguntungkan sebagai daging kambing sebagai sumber asam lemak esensial pada manusia.

\section{Kadar Asam Lemak Jenuh Daging Kambing Segar}

Kadar asam lemak jenuh yang tertinggi pada perlakuan $\mathrm{P}_{0}$ yakni $40,26 \%$, sedangkan yang terendah pada perlakuan $\mathrm{P}_{3}$ yakni 32,64.\%. Data selengkapnya dapat dilihat pada Tabel 1 .

Dari uji lanjut orthogonal kontras terlihat bahwa kadar asam lemak jenuh pada $\mathrm{P}_{0}$ berbeda sangat nyata dengan $\mathrm{P}_{1}$, $\mathrm{P}_{2}$ dan $\mathrm{P}_{3}$. Selanjutnya $\mathrm{P}_{1}$ berbeda sangat nyata dengan $\mathrm{P}_{2}$ dan $\mathrm{P}_{3}$ sedangkan $\mathrm{P}_{2}$ tidak berbeda nyata dengan $\mathrm{P}_{3}$. Kadar asam lemak jenuh yang ditambah L-karnitin $\left(\mathrm{P}_{1}\right)$ tidak mengalami penurunan bila dibanding pada $\mathrm{P}_{0}$ hal ini sejalan dengan pendapat (Owen et al., 1996) yang menyatakan bahwa suplementasi Lkarnitin tidak dapat digunakan untuk menurunkan kadar asam lemak jenuh karena L-karnitin sendiri tidak mengandung asam lemak tak jenuh. Selain itu penambahan minyak ikan dapat menurunkan kandungan asam lemak jenuh, hal ini dapat dijelaskan selain minyak sebagai sumber energi juga dapat sebagai sumber asam lemak tak jenuh sehingga mampu menurunkan kadar asam lemak jenuh dalam daging kambing. Hal ini sejalan dengan pendapat Suarez et al. (1996) yang menyatakan bahwa suplementasi asam lemak tak jenuh pada ransum berpengaruh terhadap konsentrasi asam lemak jenuh pada jaringan tubuh. Selanjutnya bila dibandingkan penelitian Sudibya et al. (2003: 2006) yang menyatakan bahwa kandungan asam lemak jenuh pada daging sapi potong yang disuplementasi dengan minyak ikan lemuru sebesar $30,50 \%$ pada penelitian ini masih dalam batas normal. Pada penelitian ini kandungan asam lemak jenuh mencapai 32,64\%, hal ini sangat menguntungkan sebagai daging kambing sebagai sumber asam lemak esensial pada manusia.

\section{Kadar Asam Lemak Omega-3 Antara Daging Segar Dan Sate Kambing}

Kadar asam lemak omega-3 pada daging segar dan sate kambing dapat dilihat pada Tabel 2 .

Hasil analisis ragam ternyata bahwa jenis perlakuan pembakaran (sate kambing) berpengaruh sangat nyata $(\mathrm{P}<0,01)$ terhadap kadar asam lemak omega-3. Terlihat pada sate kambing lebih rendah yakni $5,945 \%$ dan pada daging segar lebih tinggi yakni 5,957 \%. Hal ini sesuai dengan hasil penelitian Beltran dan Moral (1991) yang menyatakan bahwa pengasapan atau pembakaran akan mengakibatkan penurunan prosentase asam lemak tak jenuh seperti asam lemak omega-3. Selanjutnya, diperkuat oleh 
Soeparno (1994) bahwa oksidasi asamasam lemak tak jenuh lebih sering terjadi pada daging dari ternak ruminansia karena lemak pakan akan dimodifikasi secara ekstensif dalam rumen, selanjutnya asamasam lemak yang mengalami esterifikasi dibebaskan dengan hidrolisis dan asam lemak tak jenuh akan dihidrogenasi.

Tabel 2. Rataan kadar asam lemak omega-3 antara daging segar dengan sate kambing

\begin{tabular}{|c|c|c|c|c|}
\hline \multirow[t]{2}{*}{ Peubah yang diukur } & \multicolumn{2}{|c|}{ Daging segar } & \multicolumn{2}{|c|}{ Sate kambing } \\
\hline & $\mathrm{P}_{2}$ & $\mathrm{P}_{3}$ & $\mathrm{P}_{2}$ & $\mathrm{P}_{3}$ \\
\hline Kadar asam lemak omega-3 (persen) & $5,952^{\mathrm{a}}$ & $5,962^{\mathrm{a}}$ & $5,938^{b}$ & $5,952^{b}$ \\
\hline
\end{tabular}

\section{Angka Peroksida antara Daging Segar dan Sate Kambing}

Peroksida atau hidroperoksida adalah senyawa yang mengawali autooksidasi. Autooksidasi merupakan oksidasi lemak yang dapat berlangsung terus menerus setelah terbentuknya radikal bebas (Tranggono dan Setiaji, 1986). Kadar peroksida dapat diukur dengan teknik berdasarkan kemampuan peroksida membebaskan iodine dari KI atau kemampuannya mengoksidasi Ferro (Nawar, 1985). Pada penelitian ini angka peroksida diukur dengan teknik oksidasi ferro menjadi ferri karena metode ini sensitif, sampel dan hanya membutuhkan sample yang sedikit (Adnan, 1980). Pada prinsipnya ferroklorida yang ditambahkan pada peroksida terlarut benzena-metanol (minyak yang dilarutkan pelarut tersebut) mengakibatkan ferro dioksidasi oleh peroksida yang membentuk ferri yang dengan $\mathrm{NH}_{4} \mathrm{OH}$ membentuk $\mathrm{Fe}(\mathrm{CNS})_{3}$ yang berwarna merah. Intensitas warna merah yang menggambarkan angka peroksida diukur absorbansinya dengan spectrofotometer pada panjang gelombang $510 \mathrm{~nm}$.

Rataan angka peroksida dari lemak daging segar dan sate kambing berbeda sangat nyata $(\mathrm{P}<0,01)$. Angka peroksida pada sate kambing ternyata lebih tinggi yakni 0,1635 miliequivalen $/ \mathrm{kg}$ lemak dibanding pada daging segar yakni 0,1437 miliequivalen/ kg minyak, hal ini disebabkan pada proses pembakaran pembuatan sate dibutuhkan oksigen selain cahaya dan panas. Hal ini sejalan dengan pendapat Ketaren (1980) bahwa dengan adanya oksigen dari atmosfir, lemak dapat mengalami oksidasi yang dapat dipacu dengan adanya panas dan cahaya. Menurut Igene dan Pearson (1979) bahwa laju dan tingkat degradasi autooksidasi secara nyata berhubungan dengan tingkat ketidakjenuhan asam lemak. Asam lemak tak jenuh mempunyai banyak ikatan rangkap. Tranggona (1986) menambahkan bahwa reaksi permulaan (inisiasi) pada autooksidasi lemak dapat berlangsung akibat adanya metal, cahaya atau panas sehingga terbentuk radikal bebas yang dapat menghasilkan produk primer hidroperksida, selain itu menurut Tranggona dan Setiaji (1986) oksidasi lemak biasanya dimulai dengan reaksi peroksida asam lemak tak jenuh. Asam lemak tak jenuh mempunyai hidrogen labil karena terikat pada atom karbon yang berdekatan dengan ikatan rangkap sehingga mudah mengalami autooksidasi dengan inisiator cahaya dan panas membentuk produk primer hidroperoksida. 
Dilihat dari rataan angka peroksida pada daging segar dan sate kambing ternyata mempunyai angka yang masih jauh dibawah batas konsumsi yang beracun yakni $<100$ miliequivalen/ $\mathrm{kg}$ lemak).

Tabel 3. Rataan angka peroksida dan bilangan TBA antara Daging Segar dengan Sate kambing

\begin{tabular}{lcccc}
\hline \hline & \multicolumn{2}{c}{ Daging segar } & \multicolumn{2}{c}{ Sate kambing } \\
\cline { 2 - 5 } \multicolumn{1}{c}{ Peubah yang diukur } & $\mathrm{P}_{2}$ & $\mathrm{P}_{3}$ & $\mathrm{P}_{2}$ & $\mathrm{P}_{3}$ \\
\hline Angka peroksida (miliequivalen/kg lemak) & $0,1424^{\mathrm{a}}$ & $0,1450^{\mathrm{a}}$ & $0,1620^{\mathrm{b}}$ & $0,1650^{\mathrm{b}}$ \\
Bilangan TBA (mg/kg lemak) & $1,806^{\mathrm{a}}$ & $1,808^{\mathrm{a}}$ & $2,426^{\mathrm{b}}$ & $2,454^{\mathrm{b}}$ \\
\hline
\end{tabular}

* Huruf superskrip yang berbeda pada baris yang sama menunjukkan adanya perbedaan yang sangat nyata $(\mathrm{P}<0,01)$

\section{Bilangan TBA (Angka Malonaldehid) antara Daging Segar dan Sate Kambing}

Malonaldehid

( $\left.\mathrm{HOC}-\mathrm{CH}_{2}-\mathrm{COH}\right)$ adalah salah satu produk dari oksidasi lemak. Menurut Ketaren (1986) pesenyawaan malonaldehid secara teoritis dapat dihasilkan oleh pembentukan diperoksida pada gugus pentadiena yang disusul dengan pemutusan rantai molekul atau dapat dihasilkan dari penguraian monohidroperoksida (Ketaren, 1986). Menurut Tranggono (1986) malonaldehid merupakan hasil pemecahan peroksida siklis segilima yang penting dari asam linolenat. Untuk menentukan kadar malonaldehid dapat dilakukan uji TBA (asam tiobarbiturat). Uji TBA merupakan uji yang spesifik untuk hasil oksidasi asam lemak tak jenuh (PUFA) dan baik diterapkan untuk uji terhadap kadar lemak pangan yang mengandung asam lemak dengan derajat ketidakjenuhan yang lebih tinggi (Ketaren, 1986). Selanjutnya Winarno (1984) uji TBA ini dipakai untuk menentukan adanya ketengikan. Rataan terhadap kadar malonaldehid pada lemak daging segar dan sate kambing dapat dilihat pada Tabel 3 .

Hasil analisis ragam ternyata bahwa jenis perlakuan pembakaran sate berpengaruh sangat nyata $(\mathrm{P}<0,01)$ terhadap bilangan TBA lemak daging yang berarti bahwa bilangan TBA pada sate kambing lebih tinggi yakni 2,440 $\mathrm{mg} / \mathrm{kg}$ lemak dan pada daging segar yakni $1,807 \mathrm{mg} / \mathrm{kg}$ lemak. Hal ini sejalan dengan pendapat Winarno (1984) bahwa hidroperoksida bersifat sangat tidak stabil dan mudah pecah menjadi senyawa dengan rantai karbon yang lebih pendek. Berbeda dengan hidroperoksida, malonaldehid sebagai hasil oksidasi sekunder (hasil pemecahan peroksida) lebih stabil. Selain itu pada pembakaran (proses pembuatan sate) membutuhkan oksigen selain cahaya dan panas.

\section{KESIMPULAN}

Berdasarkan hasil analisis data dan pembahasan tersebut diatas dapat disimpulkan bahwa : 1) suplementasi minyak ikan tuna serta minyak ikan lemuru hingga level $5 \mathrm{ml} /$ ekor dalam ransum kambing yang mengandung 50 ppm L-karnitin mampu meningkatkan kadar asam lemak tak jenuh dari 59,74 menjadi $67,36 \%$, selanjutnya peningkatan tersebut diikuti dengan turunnya kadar asam lemak jenuh daging kambing mulai 40,26 hingga 32,64\%; 2) Proses pembakaran (sate kambing) mampu menaikan angka peroksida dari 0,1437 
hingga 0,1635 miliequivqlen/ $\mathrm{kg}$ lemak dan bilangan TBA dari 1,807 menjadi $2,440 \mathrm{mg} / \mathrm{kg}$ lemak akan tetapi menurunkan kadar asam lemak omega-3 dari 5,957 menjadi 5,945\%.

\section{DAFTAR PUSTAKA}

Adnan, M. 1980. Lipid Properties and Stability of Partially Defatted Peanuts. Disertation Doctor. University of Illinois at Urbana. Champaign.

AOAC, 1990. Official Methods of Analysis of the Association of Official Analytical Chemists. Association of Official Analytical Chemist, Washington, D.C.

Chillard, Y. 1993. Dietary fat and adipose tissue metabolism in ruminant, pigs and rodents: a review. J. Dairy Sci. 76:3897-3931.

Feller, A.G. dan D. Rudman. 1988. Role of carnitine in human nutrition. J. Nutr. 118:541-547.

Jenkins, T. C. 1993. Lipid metabolism in the rumen. J. Dairy Sci. 76:38513863.

Nawar, W.W. 1985. Lipids. Ed: Fennema. Food Chemistry. Marcell Dekker. Inc, New York.

Owen, J.L. Nelssen, R.D. Goodband, T.L. Weeden dan S.A. Blum. 1996. Effect of L-carnitine and soybean oil growth performance and body composition of early weaned pigs. J.Anim. Sci. 74:1612-1619.

Owen,L.H. Kim dan C.S. Kim. 1997. The role of L-carnitine in swine nutrition and metabolism. J.Anim. Nutr. Feed. 21(1):41-58.

Rebollar, P.G dan C. de Blas. 2005. The Digestion of Whole Soybean in Ruminants. Soybean Association Rue duluxemburg. Soyabaru @Coditec.net.www.axa-europe.org
Soeparno. 1994. Ilmu dan Teknologi Daging. Gajah Mada University Press, Yogyakarta.

Steel, R.G.D. dan J.H. Torrie. 1980.

Principles and Prosedures of Statistic. Mc Graw-Hill Inc, New York.

Sudibya, 1998. Manipulasi Kadar Kolesterol dan Asam Lemak Omega-3 Telur Ayam Melalui Penggunaan Kepala Udang Dan Minyak Ikan Lemuru. Disertasi. Program Pasca Sarjana. Institut Pertanian Bogor, Bogor.

Sudibya, Suparwi, T.R. Sutardi, H. Soeprapto dan Y. Dwi, 2003. Produksi Daging Sapi Rendah Kolesterol Yang Kaya Asam Lemak Omega-3 dan Pupuk Organik dengan EM-4 Di Kelompok Martini Indah di Kabupaten Purwodadi. Proyek Pengembangan dan Peningkatan Kemampuan Teknologi Proyek Program Iptekda VI. LIPI. Jakarta. Lembaga Penelitian UNSOED, Purwokerto.

Sudibya, D. Prabowo dan Hartoko, 2004. Suplementasi Enzim Selulase Dan Ekstrak Asam Lemak Tak Jenuh Dalam Ransum Dasar Terhadap Kualitas Dan Kuantitas Asam Lemak Tak Jenuh Telur. Journal Ilmiah. Lembaga Penelitian UNSOED. 30(02).

Sudibya, 2004. Peningkatan Kualitas Telur Ayam Melalui Suplementasi L-Karnitin dan Minyak Ikan Tuna Terhadap Kadar Asam Lemak Omega-3, Omega-6, Omega-9 dan Kadar Kolesterol. Fakultas Peternakan .Laporan Penelitian Lembaga Penelitian UNSOED, Purwokerto.

Sudibya, 2005. Suplementasi Prekursor Karnitin dan L-Karnitin Serta Minyak Ikan Tuna Terhadap Kadar 
Kolesterol dan Asam Lemak Tak Jenuh Telur Itik Tegal. Fakultas Peternakan UNSOED, Purwokerto.

Sudibya, S. Triatmojo dan H.Pratiknyo, 2006. Perbaikan Kualitas daging Sapi Melalui Transfer Omega-3 Terkapsul dan Tape Bekatul Serta Produksi Pupuk Organik dengan Starter Gama-95 Di Kelompok Ternak Sapi Potong "Sidamaju" di Kabupaten Bantul. Proyek Pengembangan dan Peningkatan Kemampuan Teknologi Proyek Program Iptekda IX. LIPI. Jakarta. Lembaga Pengabdian Kepada Madyarakat UNSOED, Purwokerto.

Sustriawan, B., R. Naufalin dan N. Aini, 2002. Mikroenkasulasi Konsentrat Asam lemak Omega-3 dari Minyak Ikan Tuna. Laporan Penelitian. Fakultas Pertanian Jurusan
Teknologi Pertanian. Lembaga Penelitian UNSOED, Purwokwerto. Tranggono, 1986. Perubahan Lemak Selama Pemanasan dan Pengaruhnya terhadap Konsumen. Seminar Keamanan Pangan dan Penyajian. Pusat Antar Universitas Pangan dan Gizi. Universitas Gadjah Mada, Yogyakarta.

Tranggono dan S. Setiaji. 1986. Kimia Lipids. Pusat Antar Universitas Pangan dan Gizi. Universitas Gadjah Mada, Yogyakarta.

Widiyastuti, T. C.H. Prayitno dan Sudibya, 2005. Pemanfaatan Kepala udang dan Suplementasi L-Carnitin Pada pakan Itik Lokal Yang mengandung Daun Lamtoro. Laporan Penelitian Fakultas Peternakan UNSOED, Purwokerto. Winarno, F.G. 1984. Kimia Pangan dan Gizi. Gramedia, Jakarta. 